\title{
The relevance of broadcasting regulation in the era of media convergence
}

\author{
Awanis Akalili \\ Department of Communication, Faculty of Social Sciences, Universitas Negeri \\ Yogyakarta, Indonesia \\ Email: awanisakalili@uny.ac.id
}

\begin{abstract}
Media convergence era becomes one of the biggest challenge for the broadcasting regulation in Indonesia. One of the form of media convergence is ownership convergence, that is the ownership merger of media company as various platform under one company name. The purpose of this study is to analyze relevance Broadcasting Law Number 32, 2002 in the era of media convergence by Media Nusantara Citra Tbk (MNC) case of ownership convergence. Using library research method, this research found that the Broadcasting Law Number 32, 2002 does not yet include media convergence issue, in which convergence ownership is included. This law depicted only the limitation of media ownership, where the limitation itself is not explained in detail. With the unclear convergence ownership regulation, MNC could be freely expanding its business network of broadcasting media (TV and radio), printed media, even online media. Moreover, MNC also has the control to three of Indonesia's biggest TV broadcasting media, namely RCTI, Global TV and MNC TV. This urges Indonesia's government to act immediately by revising the regulation of
\end{abstract}


media broadcasting to be adaptable to the era of media convergence, specifically to convergence ownership issue.

Keywords: Broadcasting Regulation, Media Convergence, Convergence Ownership, MNC

\section{Introduction}

Developed from the conventional, then new media, to today's media convergence, media regulation change is essential to media convergence. In Indonesia, the government related to media and various media institution have tried their best to issue various types of media regulation, including the Broadcasting Law Number 32, 2002. In fact, broadcasting media difficult situation has yet to improve. For example, for the concern on media ownership issue. The ownership issue in this media convergence era is much more complicated due to the emergence of new concepts, such as convergence ownership.

In his book "The Meaning of Convergence" (from Quinn, 2004:112), Rich Gordon defined convergence ownership as a form of convergence to media companies' ownership, be it broadcasting media, printed media or online media. This concept describes that media ownership could also be merged under one ownership. Attention to the locus media ownership finally put a pressure for a change on broadcasting media regulation, as the current one is not relevant to today's media situation and condition.

Discussion on the law is necessary in order to understand media convergence and regulation in Indonesia, for the Broadcasting Law Number 32, 2002 has not fully work in regulating media convergence issue, including convergence ownership (kpi.go.id, 2016). For example, in Section 18 Article 1, the government has defined that "kepemilikan dan penguasaan lembaga penyiaran swasta oleh satu orang atau satu badan hukum, baik di satu wilayah siaran maupun di beberapa wilayah siaran, dibatasi (Ownership and authorization of Private Broadcasting Organization under one name or one organization law, be it of one broadcasting area or in certain broadcasting areas, are limited)". Even though it is substantively written that media ownership is limited, but the regulation should clarify the form and type of limitation on what and how it works in order to comply with it. This, in the end, is out of sync with the media business development that gave birth to convergence ownership, where the regulation 
is not kept up to anticipate the reality. A company did merge the ownership of media under one company. In this case, the media referred to is PT. Media Nusantara Citra Tbk, known as MNC.

MNC is the biggest company owned by Harry Tanoesoedibjo, with four media group under its authorization, that are PT Rajawali Citra Televisi Indonesia (RCTI), PT. Global Informasi Bermutu/GIB, PT Cipta Televisi Pendidikan Indonesia/CTPI and PT MNC Networks/MNCN (Rahayu et.al, 2014:48). From these media groups, MNC has leastwise three forms of media; broadcasting media (TV and radio), printed media, and online media. The company, seen from the broadcasting media only, have the control over three biggest TV station in Indonesia; RCTI, Global TV and MNC TV (Rahayu et.al, 2014:18-19). A number of academics have spoken up about this tremendous power the MNC company have over the quota violation, as well as the monopoly of media ownership, which are clearly violating the Broadcasting Law Number 32, 2002 Section 18 Article 1. The company is still proudly in business without any hassle until today (nasional.kompas.com, 2011). This convergence ownership issue by MNC has always been an attractive study among people, where the government decisive action is still invisible until today. The researcher choose $\mathrm{MNC}$ as a case study because of the company scale in Indonesia with direct authorization over four media group, including three biggest TV station (RCTI, Global TV and MNC TV) in the country (Rahayu et.al, 2014:18-19).

This paper will analyze the relevance of convergence ownership by MNC to the country's regulation defined in the Broadcasting Law Number 32, 2002. To begin, the researcher believe that the current broadcasting regulation (Broadcasting Law Number 32, 2002) is not relevant anymore to media convergence development happen today, especially the convergence ownership studied from MNC case of media ownership. To focus on the case, it is clear that the Broadcasting Law Number 32, 2002 is the only broadcasting media regulation there is in Indonesia. For 15 years now, the regulation used for the media broadcasting field is still the same law, no matter how developed the technology era is, even more after the emergence of media convergence today. This paper will analyze the Broadcasting Law Number 32, 2002 relevance to the convergence era, especially on the case of convergence ownership. To make it an understandable reading, this paper will be structured from the Introduction, followed with the Discussion on regulation in the context of media convergence, flashback on Broadcasting Law Number 32, 2002, the weak tendency of broadcasting regulation to media convergence issue, convergence ownership in 
Indonesia's broadcasting media: mapping of MNC media ownership, Theoretic Analysis: Review of the Broadcasting Law Number 32, 2002 relevancy with MNC business attitude, and the final chapter is the Closing.

\section{Methods}

This paper uses library study method, where the researcher collected various data from books, websites or journals in relevance with the keywords of this paper. From the collected data, the researcher analyze the relevance between the regulation (Broadcasting Law Number 32, 2002) and MNC case.

\section{Results And Discussion}

\section{Regulation in the Concept of Media Convergence}

The term of media convergence has been interpreted as media merger or integration in one platform (Jenkins, 2006). Media convergence does not only change the individual attitude in accessing information, but also contribute to the structural order of industry, the government and regulation on convergence impact (Jenkins, 2006).

Regulation has become one form of regulation in the era of media convergence Faur and David Levi (2011: 96) defined regulation as limitation on activities of the country, the people, the government and the market. Aslama and Napoli in their journal entitled "Diversity 2.0: "Rethinking audiences, participation and policies" (quoted from Rahayu et.al, 2016:58), revealed that media convergence also brings opportunity to a change in regulation. Moreover, Aslama and Napoli also analyze that media convergence have the power to disrupt the current model of media business, so that the regulation has lost its relevance (Rahayu et.al, 2016:58).

Media rapid development requires regulation that is adaptive to real situation in order to keep up with the trend (Storsul \& Trine, 2007:277). Even more so after media convergence era, academics demanding media regulation reshuffle. From their research, Storsul and Trine (2007:277) also stated that television broadcasting media is an urgent concern in the concept of media convergence. Television as the 'best soil' for ownership business has been very 'fertile'; it needs more intensive regulation compared to other media platform (Storsul \& Trine, 2007:281). Even more so, media convergence era springs up chances of ownership monopoly because it inclined to the industry authorization over certain media. 
Regulation that administer media convergence is still in RUU or Rancangan Undang-Undang (Draft Bill) . UU Konvergensi Media (Media Convergence Law) is intended to incorporate three fundamental aspects of media regulation, that are UU ITE (Information and Electronic Transaction Law), UU Telekomunikasi (Telecommunication Law) and UU Penyiaran (Broadcasting Law).

\section{Flashback on the Broadcasting Law Number 32, 2002}

The Broadcasting Law Number 32, 2002 becomes the only broadcasting media regulation that is arranged with the spirit of democracy (Rahayu et.al, 2014:vii). Regulation is considered necessary for broadcasting media, as it uses ownership right and free to air nature of the activity in public and also that it is terrestrial (Rahayu et.al, 2015: 54). In general, the content of this Broadcasting Law is about the regulation on broadcasting media in its use of public rights, including content, broadcasting time, broadcasting area, and ownership (Rahayu et.al, 2015: 48). From a series of regulation in this law, the researcher take the regulation on media ownership as an item to analyze.

Democracy and its idea of having balanced power between the government, media business people and society, becomes the baseline of this law mentioned. The fact, however, capitalism on media ownership seems to be simply a sin that has always been forgiven. On the other hand, the Broadcasting Law Number 32, 2002 has regulated media ownership, specifically on Chapter II (principle, purpose, function and direction), Section 5 Article 7, "Mencegah monopoli kepemilikan dan mendukung persaingan yang sehat di bidang penyiaran (to prevent any act of ownership monopoly and support fair competition in broadcasting field.)" It is also stated in Part 5 of Private Broadcasting Organization (Lembaga Penyiaran Swasta) that "Kepemilikan dan penguasaan Lembaga Penyiaran Swasta oleh satu orang atau satu badan hukum, baik di satu wilayah siaran maupun di beberapa wilayah siaran, dibatasi (Ownership and authorization of Private Broadcasting Organization under one name or one organization law, be it of one broadcasting area or in certain broadcasting areas, are limited)"

"Mendukung persaingan yang sehat (support fair competition)" and "kepemilikan industri media swasta dibatasi (that private media industry ownership is limited)", are two points that are ambiguous or unclear. These statements do not provide detailed information on the expected fair competition and the indicator of media industry ownership limitation. This depicts today's situation that there is centralization on broadcasting station ownership and authorization, where only particular parties have the privilege to (Rianto et.al, 
2012: 58-61). This can be analyzed not only from the Broadcasting Law Number 32,2002 , but also from the weak media regulator performance in overseeing the situation. This leads to cross ownership, a merger of broadcasting media, impacting on suppressed information and both politic and economic capitalism in broadcasting media (Rianto et.al, 2012: 58-61).

\section{Weak Broadcasting Regulation in the Context of Media Convergence}

The change to the current broadcasting regulation in Indonesia should be discussed deeply on its urgency in today's situation and condition. A number of academics, in the mean time, has voiced their concern to support urgent change on the Broadcasting Law Number 32, 2002 (Permana, 2016: Supadiyanto, 2019). The government has responded by proposing UU Konvergensi Media (Media Convergence Law) that is yet to be made official until today.

The concern is that media convergence era could diminish variety of content aspect, and media could actually be a business of ownership for the investor (Rahayu et.al, 2014). This could be observed on the visible media conglomeration phenomena around us. Even more, the broadcasting regulation could not handle the monotonous content problem that media convergence era has brought to the table. The biggest problem is that the government seems to be powerless against the private television company domination, which leads to even smaller chance for local television (Rahayu et.al, 2014). This supports the idea that media regulation in Indonesia is yet ready to adapt to today's technological development, that is in the era of media convergence.

To analyze it from theoretic approach, the issue of weak broadcasting regulation actually happened as the country has not prepared to the media convergence happening right now (Lunt \& Sonia, 2011). This should put the government a pressure to make modification, reshuffle or even changes to media regulation. Peter Lunt and Sonia Livingstone in "Media Regulation: Governance and the Interests of Citizen and Consumers" (2011) described that a concept of media regulation is when the regulation cannot put stability to the country's condition, immediate change should be considered by the government. As the regulation needs immediate change, the current clearly cannot play its part to stabilize the real situation. Peter and Sonia (2011) reaffirmed that society has the right to voice their concern in this issue if the country cannot assure immediate regulation change. The public voice should bring greater urgency to pressure the government as it is part of their right as the people of the country.

Lara Fielden (2016:473-474) in her journal entitled "UK Press Regulation: 
Taking Account of Media Convergence" also stated that media convergence demands the urgency of media regulation change, specifically to broadcasting media. Broadcasting media is considered to make immediate regulation change than other media forms, as it causes wider impact and is closer to the public interest (Fielden, 2016:474). In broadcasting field, especially, media convergence leads to monotonous content, as well as media ownership monopoly. If regulation change is not happening in the near future, these content issue and media conglomeration will rule out the public right.

Necessarily, the government of Indonesia should be firm and detailed on its media regulation arrangement and process, as mentioned by Ross Tapsell in his journal "Platform Convergence in Indonesia: Challenges and Opportunities for Media Freedom" (2015), that media convergence does give impact to media conglomeration. Unspecified and ambiguous regulation, and the lax government performance regarding this issue seems to give investors freedom to media ownership conglomeration (Tapsell, 2015). Based on theoretic concept, supported with other academic findings related to media regulation, there should be some responses from the country's government on the Broadcasting Law Number 32, 2002 revision, as it could not fully regulate all aspects in today's era of media convergence.

\section{Convergence Ownership of Broadcasting Media in Indonesia: MNC Media Ownership Mapping}

Refer to convergence ownership, one of the five dimensions of media convergence proposed by Rich Gordon, is that media convergence allows a merger of ownership from company of the same or different platform (in Jin 2013: 6). Convergence ownership does not only trigger capitalization on media ownership, but also the tendency to relatively the same content, means diversity of content is no longer present (in Jin 2013: 6). With the same idea, Doyle in "Media Ownership: the Economics and Politics of Convergence and Concentration in the UK and European Media" also stated that merger ownership could increase media monopoly and media conglomeration (Doyle, 2002:21-22).

Refer to Rich Gordon's convergence ownership concept (in Quinn, 2004:112), media ownership phenomena in Indonesia has become a serious concern. Convergence ownership could be seen from company merger under one media platform or various media forms under one ownership. A case that describes convergence ownership is what happens to the giant company, MNC. 
MNC, an abbreviation of PT. Media Nusantara Citra Tbk. MNC company is now under the name of Hary Tanoesoedibjo. Through MNC, not only that Hary owns four broadcasting media (RCTI, GIB, CTPI and MNCN) but also he manages other media business, such as printed media and online media. The following is the structure mapping of MNC broadcasting media ownership business

\section{Ownership Business Mapping PT Media Nusantara Citra Tbk (MNC)}

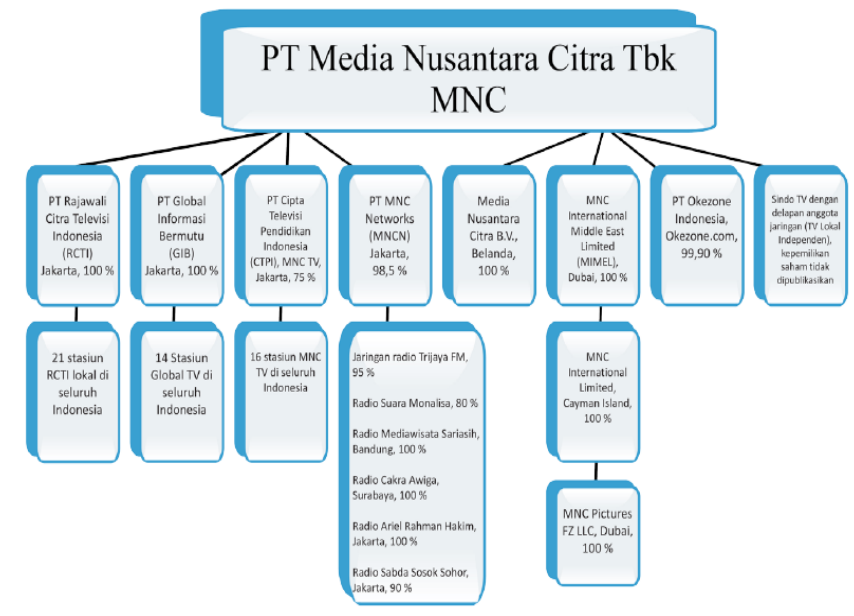

(Rahayu et.al, 2014:22)

Convergence ownership is clearly shown in the mapping above, in which MNC has the authority over three biggest TV station in Indonesia, namely RCTI, Global TV and MNC TV (Rahayu et.al, 2014:18-19). In addition, MNC also managed to run radio network business, even online media(Rahayu et.al, 2014). In a book entitled "Kepemilikan dan Intervensi Siaran", Rahayu and PR2Media (Pemantau Regulasi dan Regulator Media/Regulation Monitor and Media Regulator) researcher team arrange mapping of 22 radio network under the ownership of MNC group.

Media ownership monopoly is clearly visible from the two mappings above. MNC has the leisure and authority to accommodate and integrate various media platform, including TV, radio, printed media, and even online media, under one company label. Hary Tanoesoedibjo as the President Director claimed that MNC labels are all stand-alone (Rahayu et.al, 2014). Media 
ownership issue accusation directed to him got shifted as he claimed himself as just an ordinary director. He stated that each media is but under others' name, not his. In fact, his own argument got him back.

\section{Mapping of MNC Group Radio Networking}

\begin{tabular}{|c|l|c|l|}
\hline No & \multicolumn{1}{|c|}{ Nama Radio } & No & \multicolumn{1}{|c|}{ Nama Radio } \\
\hline 1 & Global Radio & 12 & Sindo Radio Dumai \\
\hline 2 & V Radio & 13 & Sindo Radio Pekanbaru \\
\hline 3 & Sindo Radio Network Jakarta (1990) & 14 & Sindo Radio Pontianak \\
\hline 4 & Sindo Radio Surabaya & 15 & Sindo Radio Manado \\
\hline 5 & Sindo Radio Medan & 16 & Sindo Radio Banjarmasin \\
\hline 6 & Sindo Radio Madiun & 17 & Sindo Radio Bandung \\
\hline 7 & Sindo Radio Palembang & 18 & Sindo Radio Semarang \\
\hline 8 & Sindo Radio Lubuk Linggau & 19 & Sindo Radio Yogyakarta \\
\hline 9 & Sindo Radio Prabumulih & 20 & Sindo Radio Makassar \\
\hline 10 & Sindo Radio Lahat & 21 & Sindo Radio Baturaja \\
\hline 11 & Sindo Radio Kendari & 22 & Radio Dangdut Indonesia \\
\hline
\end{tabular}

(Rahayu et.al, 2014:102)

From a research conducted by PR2Media, it is recorded that in 2014 Hary Tanoesoedibjo placed his trusted people to be the Chief Editor in Global TV and he also let him have a share in managing news content for RCTI (Rahayu et.al, 2014:146). This Chief Editor issue has allowed similarity in content, which clearly degrades the principal of democracy where diversity of content is essential. Exceedingly, not only for Hary Tanoesoedibjo is the owner of MNC, but also he is politician of Hanura party. These facts alone will give bigger picture on how he will direct the news and broadcast the information. It has been proven that from 2 to 15 April 2013, KPI had recorded 11 news related to Hanura broad casted in three different television station of MNC, which were RCTI, MNC TV and Global TV (Rahayu et.al, 2014:181).

From all these information, what is important is that convergence ownership where merger and autonomy of ownership, and centralization and concentration could actually influence media content with irrelevance and repeated information (Rahayu et.al, 2015: 56). The investor, in this case, gets the most profit to the situation. Convergence ownership create new opportunities in new service or market with relatively low cost but wide impact to society (Rahayu et.al, 2016:76). With the ease and comfort provided by one media platform, the society is to believe they get the benefit. However, the true fact is that the media owner is still the one enjoying the most profit. 


\section{Theoretic Analysis: Reviewing the Relevance of the Broadcasting Law Number 32, 2002 in Ownership Convergence Case by MNC}

To review on regulation and media ownership of MNC company label, there are two basic concepts used to analyze this phenomena. The first concept is dimension of convergence in media proposed by Rich Cordon, that is convergence ownership. The second is the concept of ownership limitation regulated in the Broadcasting Law Number 32, 2002.

The first analysis is that the media monopoly caused by convergence ownership is considered reasonable. Merger, cross ownership and various media ownership in one label is understandable, as media business is the easiest field for monopoly practices. 25-26). Media convergence that claimed easy information access for society in one platform is considered a trick for society to hide the fact that media owner is still the one beneficial from it.

In MNC Group case, convergence ownership is described from the ownership merger of some television media (RCTI, Global TV, MNC TV), radio network, printed media, and online media portal (Rahayu et.al, 2014). $\mathrm{MNC}$, in this case, has the authority over almost all forms of media, including printed media, electronic media or new media with the Internet support. Convergence ownership as one of media convergence dimension seems to be permissive over media monopoly as depicted in $\mathrm{MNC}$ case.

In the context of convergence ownership, $\mathrm{MNC}$ has the leisure to merge various media platforms under one ownership. Convergence ownership by Gordon could be used to analyze media capitalization. Media business runs smoothly without any intervention. Gordon explained that convergence ownership does not only benefit media owner, but also it leads to content similarity (Jin 2013: 6). This has been discussed above, where repetition on Hary Tanoesoedibjo and Hanura aired on RCTI, MNC TV and Global TV.

The second analysis is regulation view on MNC Group case. Here is the important question; does the Broadcasting Law Number 32, 2002 work as it should be to regulate this type of case of convergence ownership? The answer is, it does not completely work yet. Arguments build from this question is a fact that shows weak tendency on broadcasting regulation in Indonesia. In a rough saying, the regulation is considered losing to the media ownership monopoly committed by individuals; which is exactly what happened in MNC.

Regulation on ownership limitation is written in two sections in the Broadcasting Law Number 32, 2002. In Chapter II (principle, purpose, function 
and direction), Section 5 Article 7 "Mencegah monopoli kepemilikan dan mendukung persaingan yang sehat di bidang penyiaran (to prevent ownership monopoly and support fair competition in broadcasting field)". The problem here is that the definition of "sehat (fair)" is not explained in detail. Thus, business competition comes from various sector in media industry. For example, one media did copy, take and broadcast content from another media of the same ownership. In this case, it is proven with evidence that MNC did copy the information to be broad casted to all three of its television stations. Obviously, this type of business is fraudulent; very minimum content production to reach wider society.

The second, MNC act of ownership conglomeration disregards what is regulated in Section 18 Article 1 about "Kepemilikan dan penguasaan Lembaga Penyiaran Swasta oleh satu orang atau satu badan hukum, baik di satu wilayah siaran maupun di beberapa wilayah siaran, dibatasi (Ownership and authorization of Private Broadcasting Organization under one name or one organization law, be it of one broadcasting area or in certain broadcasting areas, are limited)". "Dibatasi (limited)" is an ambiguous diction in this case; no further explanation on what and how exactly this limitation is in detail. Broadcasting law regulates that commercial broadcasting quota is given 10 times for television In reality, three of the commercial broadcasting quotas are of $\mathrm{MNC}$ alone, in all the company's television station (RCTI, Global TV, and MNC TV).

To review this case, Jenkins (in Tapsell, 2014:16) explained that media convergence will increase and strengthen media corporation monopoly, as well as the emergence of media oligopoly. The country, Indonesia, has to put immediate act in order to create law that regulates limitation on media industry.

Baldwin and Cave (in Lunt \& Sonia, 2012:21) described regulation theory as a protest to the government to officially arrange media regulation in response to the changes in economy, monopoly, public interest, and business people. This theory strongly demands the government to make arrangement on the regulation, specifically the Broadcasting Law Number 32, 2002.

The fast growing era demand more adaptive media regulation. Bar and Christian (2008) in a journal "US Communication Policy After Convergence" explained that related to regulation, the government has two options of response. The first is to choose to regulate new media with the currently used regulation, or to revise to the current regulation (Bar \& Christian, 2008:2). Indonesia, on the other hand, has chosen the second option, that is to revise the law by arranging Broadcasting Law Draft Number 32, 2002. 
Society has strongly demanded that this revision is made official for the regulation to be more relevant to the era of media convergence. The content of Broadcasting Law Number 32, 2002 has yet adapted to the current condition that diversity of content, diversity of platform and diversity of ownership have no regulation basis, despite it's important aspect (Masduki, 2007:114).

As a response, academics has spoken up in front of the public. If their demand is not fulfilled, there is possibility of frequency efficiency and improvement on technique quality. These could open and multiply fair opportunities to the growth of broadcasting industry. Fair competition is yet to be seen when the law and regulation are ambiguous and unclear (Rahayu et.al, 2015: 58).

Revision demand on UU Penyiaran No. 32 Tahun 2002 is also encouraged by Amir Effendi Siregar. Amir said that the current Broadcasting Law needs to be revised, so it would be more dynamic in corresponding to broadcasting regulation issues in this era. Thus, the government should include elements of media convergence. Particularly, ownership issue should be included, so that it will help minimize fault to media monopoly committed under one label of company (kpi.go.id, 2016).

\section{Conclusion}

As a media convergence dimension, convergence ownership has strengthen the practice of capitalism on television media broadcasting in this country. The researcher conclude that the impact of convergence ownership does not only influence media ownership, but also to the fair competition of business. MNC case of ownership monopoly raise a question on the role of broadcasting regulation. The Broadcasting Law Number 32, 2002 is considered ambiguous and unclear where it regulates only a small part of broadcasting ethic, that is "menuntut persaingan bisnis yang sehat (demand a fair business competition)" from Section 5 Article 7", and "kepemilikan dibatasi (ownership limitation)" from Section 18 Article 1. In fact, these two sections could not regulate the media ownership convergence in the MNC company case. This company is known to own three biggest television stations (RCTI, Global TV, MNC TV), and has the authority over 22 radio networking channel, printed media and online media portal (okezone.com) ownership. Ownership capitalism that impacts the business competition demanded revision on the Broadcasting Law Number 32, 2002. The revision, which currently still on the draft stage, is 
arranged to update the current regulation This draft of regulation is considered to include media convergence element, that is media ownership convergence.

From the point of view of an academic of media and communication studies, the researcher propose the following suggestions regarding the issue. The first suggestion is that the government to immediately revise the regulation and include detailed information regarding media ownership written in Broadcasting Law Number 32, 2002 that will be revised and updated to the new RUU Penyiaran Nomor 32 Tahun 2002. The second, it is suggested that the government could officiate different regulation for each media platform. This is so that each media will be handled differently based on its characteristic. The last but not least, organization that is in charge of the regulation making should remain neutral in the process and without any intervention from the government and industry. This neutrality is necessary to avoid domination of media industry interest in policy making. Finally, this issue does not stop after the revision or change on the regulation. The government should take firm action to the individuals committed ownership violation for teh sake of the country's better media environment.

\section{References}

Bar, F., \& Sandvig, C. (2008). US communication policy after convergence. Media, Culture $\mathcal{E}$ Society, 30(4), 531-550. DOI: 10.1177/0163443708091181.

Doyle, G. (2002). Media ownership: The economics and politics of convergence and concentration in the UK and European Media. London: Sage

Faur, D. L. (2011). Handbook on the politics of regulation. Cheltenham: Edward Elgar. Fielden, L. (2016). UK press regulation: Taking account of media convergence. Convergence: The International Journal of Research into New Media Technologies. 22(5) 472-477. https://doi.org/10.1177\%2F1354856516660807

Jenkins, H. (2006). Convergence culture: Where old and new media collide. New York: New York University Press.

Jin, D. Y. (2013). De-convergence of global media industries. New York: Routledge

Kpi.go.id. (2016). Akomodasi Konvergensi Media dalam Perubahan UU Penyiaran. https://www.kpi.go.id/index.php/lihat-terkini/38-dalam-negeri/33272akomodasi-konvergensi-dalam-perubahan-uu-penyiaran. Accessed on 3rd March 2017 
Lunt, P. \& Livingstone.S. (2011. Media regulation: Governance and the interests of citizens and consumers. London: SAGE.

Masduki. (2007). Regulasi penyiaran: Dari otoriter ke liberal. Yogyakarta: LKiS

Nasional.kompas.com. (2011). Monopoli Kepemilikan Lembaga Penyiaran Langgar UU. http://nasional.kompas.com/read/2011/10/18/22535833/ Monopoli.Kepemilikan.Lembaga.Penyiaran.Langgar.UU. Accessed on 23rd May 2017

Permana, S. I. (2016). 14 Tahun UU Penyiaran, Ratusan Akademisi Sampaikan Kritik. https://news.detik.com/berita/d-3382640/14-tahun-uu-penyiaranratusan-akademisi-sampaikan-kritik. Accessed on 24 May 2017

Quinn, S. (2004). An intersection of ideals: Journalism, profits, technology and convergence.Convergence: The Journal Research Into New Media Technologies. 10(4). 109-123.

Rahayu et.al. (2014). Kepemilikan dan intervensi siaran. Yogyakarta: PR2Media

Rahayu et.al. (2015). Menegakkan kedaulatan telekomunikasi dan penyiaran di Indonesia. Yogyakarta: PR2Media

Rahayu et.al. (2016). Membangun sistem komunikasi Indonesia. Yogyakarta: PR2Media

Rianto et.al. (2012). Dominasi TV swasta (nasional): Tergerusnya keberagaman isi dan kepemilikan. Yogyakarta: PR2Media

Soderlund, W. C. (2012). Cross-media ownership and democratic practice in Canada: Content sharing and the impact of new media. Canada: The University of Alberta Press.

Storsul, T. \& Syvertsen. T. (2007). The impact of convergence on European television policy. Convergence: The International Journal of Research into New Media Technologies, 13(3), 275-291. https://doi. org/10.1177\%2F1354856507079177.

Supadiyanto, S. (2019). Pornography in print media: legal review of pornografic content on mantra tabloid in indonesia. Journal of Social Studies (JSS), 15(1). 47-62. https://doi.org/10.21831/jss.v15i1.25232

Tapsell, R. (2015). Platform convergence in Indonesia: Challenges and opportunities for media freedom. Convergence: The International Journal of Research into New Media Technologies. 21(2) 182-197. https://doi. org $/ 10.1177 \% 2 \mathrm{~F} 1354856514531527$.

Undang-Undang Penyiaran No. 32 Tahun 2002 (Broadcasting Law Number 32, 2002 in Indonesia) 